\title{
INDUCTION OF RESISTANCE IN CHICKPEA (Cicer arietinum L.) AGAINST Ascochyta rabiei BY APPLYING CHEMICALS AND PLANT EXTRACTS
}

\author{
M. Usman Ghazanfar ${ }^{1 *}$, Waqas Wakil², and Shahbaz Talib Sahi ${ }^{3}$
}

\begin{abstract}
Since new fungicides are scarce in the market and because of environmental problems, researchers are now emphasizing other alternatives, such as the genetic potential of plants, resistance against pathogens, and the use of biotic and abiotic agents to develop induced or acquired resistance. We investigated the role of resistance-inducing substances (chemicals and plant extracts) in three chickpea cvs. C-44, Pb-91, and Bittle-98 in field experiments against Ascochyta blight disease. These cultivars were selected on the basis of better yield potential shown in previous experiments. Aqueous solution of salicylic acid (SA) at $0.5,1.0$, and $1.5 \mathrm{mM}$; acibenzolar-S-methyl (ASM) at 0.4, 0.8, and $1.2 \mathrm{mM}$; and $\mathrm{KOH}$ at 25, 50, and $75 \mathrm{mM}$ were applied, whereas Azadirachta indica A. Juss., Datura metel L., and Allium sativum L. plant extracts were applied at 5, 10, and 15\%. Disease reduction data was recorded at different intervals from 4 to $14 \mathrm{~d}$ after being induced and inoculated with the pathogen. Overall results revealed that significant disease reduction (79.3\%) was provided by ASM in the cv. C-44 at $1.2 \mathrm{mM}$ compared with SA, whereas the least significant was $\mathrm{KOH}$. Maximum disease reduction (43.5\%) against disease in the plant extracts was observed by applying $A$. indica leaf extract, but $D$. metel and $A$. sativum extracts were not effective. Our findings suggest that enhancing resistance before infecting chickpea plants could be an innovative control method for Ascochyta blight of chickpea.
\end{abstract}

Key words: Induced resistance, acibenzolar-S-methyl, salicylic acid, Azadirachta indica, Datura metel.

\section{INTRODUCTION}

Chickpea blight caused by Ascochyta rabiei (Pass.) Labrousse is the most devastating chickpea (Cicer arietinum L.) foliar disease in many countries (Pande et al., 2005). This disease has caused considerable losses ranging from 5 to $100 \%$ around the world (Haware, 1998). In Pakistan, the number of epiphytotics has been reported with complete crop failure (Aslam, 1984). Chickpea breeders in Pakistan are focusing their attention on developing blight resistant cultivars (Iqbal et al., 1993; Ilyas et al., 2007). Different aspects of this disease, such as severity, lifecycle, pathogenicity, epidemiology, breeding for resistance, cultural, and chemical control measures

${ }^{1}$ University of Sargodha, University College of Agriculture, Sargodha, Pakistan.

"Corresponding author (usmanghazanfar1073@yahoo.com).

${ }^{2}$ University of Agriculture, Department of Agricultural Entomology, Faisalabad, Pakistan.

${ }^{3}$ University of Agriculture, Department of Plant Pathology,

Faisalabad, Pakistan.

Received: 20 August 2010.

Accepted: 7 October 2010 have been successfully explored in different parts of the world, although this disease still poses a great threat to the chickpea crop (Mohamed et al., 2009; Trapero-Casas and Kaiser, 2009). This disease can be managed with different fungicides (Gan et al., 2006), but the most economical management strategy is using resistant cultivars (Türkkan and Dolar, 2009). However, breeding resistant chickpea cultivars is more difficult because of the great variation in A. rabiei isolate pathogenicity (Ali et al., 2009).

Since the pathogen's nature is constantly changing (Chaudhry et al., 2001), already resistant cultivars become susceptible. Therefore, what is needed to restrain or alleviate infection are recent management methods such as induction of resistance, which is a new technology for plant disease control based on activating the plant's own defense system with the help of low molecular weight synthetic molecules (Cohen et al., 1999). Induced resistance is defined as an increase in the level of resistance without any changes in the basic genetic constitution (Baysal, 2001), which is associated with an enhanced ability of the plant to resist infection by an intense activation of defense responses. This method is the alternative to fungicides to protect plants since there is 
greater awareness about the harmful effect of fungicides on the natural ecosystem (Vimala and Suriachandraselvan, 2009). At the same time, development of pathogen resistance to pesticides, real and perceived health and environmental concerns increase the popularity of organic crops and sustainable agriculture (Kuć, 2001). Induced resistance can appear locally (i.e., in the organ where resistance is applied), or it may be systemic to the plant part which is spatially separated from the site of inducing agents (Walter, 2009). There are at least three types of induced resistance: systemic acquired resistance (SAR) developed by localized necrosis resulting in hypersensitive reaction (HSR), wound-induced resistance usually caused by insect feeding, and infection by virulent pathogen or by treatment with certain chemically induced systemic resistance (ISR) that developed due to plant growth colonization promoting rhizobacteria (PGPR). In systemic acquired resistance, an invading pathogen is not needed and various defense pathways are stimulated in the induced plant resulting in the production of diverse defense products, including lignin and pathogenesisrelated proteins, some of which show chitinase or $\beta-1,3-$ glucanase activity (van Loon, 1997; Neuhaus, 1999), phytoalexins, thionins, and defensins (Kessmann et al., 1994; Sticher et al., 1997; Kombrink and Schmelzer, 2001; Ziadi et al., 2001).

Induced resistance is an age-old phenomenon for managing plant diseases that was first reported by Ray (1901) in rust diseases. Numerous studies have shown the appearance of defense responses against several important plant diseases (Abo-Elyousr and El-Hendawy, 2008; Jiang et al., 2008). Various chemicals, such as salicylic acid, isonicotinic acid (INA), benzothiadiazole (BTH), Rigel (salicylic acid analog), $\beta$-aminobutyric acid (BABA), $\mathrm{NaClO}_{3}, \mathrm{HgCl}_{2}$, probenazole, paraquat, polyacrylic acid, $\mathrm{SiO}_{2}$, Messenger (Harpin protein), and Phoenix (potassium phosphate) have been used to induce resistance against fungi, bacteria, and viruses (Schneider et al., 1996; Kuć, 2001; Percival et al., 2009). Extracts of various plants have also been explored as natural resistance inducers such as Azadirachta indica Juss. against Alternaria leaf spot on sesame (Guleria and Kumar, 2006), Datura metel L. against Rhizoctonia solani, Xanthomonas oryzae pv. oryzae, and Alternaria solani (Kagale et al., 2004; Latha et al., 2009). Few studies have been carried out on induction of resistance in Ascochyta blight of chickpea, except Chaudhry et al. (2001) who studied the induction mechanism in susceptible chickpea cv. C-727 by applying an aqueous solution of salicylic acid dipotassium hydrogen phosphate and cuprous chloride and found that all treatments showed significant results.

The objective of our studies was to evaluate the reduction in Ascochyta blight disease as a result of induced resistance by applying simple chemicals and plant extracts.

\section{MATERIALS AND METHODS}

Chickpea cvs. C-44, Pb-91 and Bittle-98, which were susceptible but had shown good yield character in a previous experiment, seeds were cultivated in small plots of $6006 \mathrm{~m}^{2}$ in the experimental area of the Department of Plant Pathology, University of Agriculture, Faisalabad, Pakistan during the 2007-2008 season. The experiment was laid out under factorial arrangement of randomized complete block design with three replicates of 39 plots. Eighteen plots were induced and inoculated, three plots served as controls while the remaining 18 plots were induced but not inoculated. Each plot had six rows of 15 chickpea plants.

Extracts of neem (Azadirachta indica), Datura (Datura metel L.), and garlic (Allium sativum L.) were prepared in the phytobacteriology laboratory of the Department of Plant Pathology, University of Agriculture, Faisalabad. Neem and datura leaves were collected from the agronomic research area and square $\mathrm{N}^{\circ} 32$, University of Agriculture, Faisalabad while garlic cloves were purchased from a local market. Neem and datura leaves were thoroughly washed under tap water, materials were surface-sterilized with $1 \%$ sodium hypochlorite solution, and then washed with sterilized water. Leaves were homogenized (Yellow line DI-25 Basic, GmbH and CO, Germany) in sterile distilled water at 1:1 (w/v) and filtered through muslin cloth to produce a $100 \%$ crude plant extract. Garlic extract was prepared from fresh samples; the dry outer peel of the cloves was first removed, surface-sterilized for $2 \mathrm{~min}$ in $70 \%$ ethanol, and washed in three changes of sterile distilled water. Cloves were crushed into a pulp in a sterile porcelain mortar with a pestle; pulp was suspended in $100 \mathrm{~mL}$ water in a $250-\mathrm{mL}$ Erlenmeyer flask, and filtered through muslin cloth. Plant extracts were heated to $40{ }^{\circ} \mathrm{C}$ for $10 \mathrm{~min}$ to avoid contamination (Jaganathan and Narasimhan, 1988) and diluted to the required concentration $(5 \%, 10 \%$, and $15 \%)$ with sterile distilled water (v/v).

Salicylic acid (Sigma Aldrich, Germany) and $\mathrm{KOH}$ (Sigma Aldrich, Germany), purchased from the market, and Bion ${ }^{\circledR}$ (acibenzolar-S-methyl), provided by Syngenta Crop Protection, Germany, were the chemicals used to induce resistance. Aqueous solution of salicylic acid (SA) 0.5, 1.0, and $1.5 \mathrm{mM}$; acibenzolar-S-methyl (ASM) 0.4,

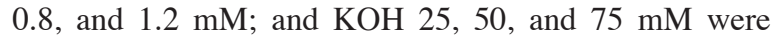
applied. However, all plant extracts were applied at 5\%, $10 \%$, and $15 \%$, respectively. At the early flowering stage, all the resistance inducing agents (chemicals and plant extracts) were sprayed onto the plants until runoff while control plants were sprayed with distilled water. 
Mass preparation of already isolated and preserved A. rabiei inoculums was carried out by the method of Ilyas and Khan (1986). Conidial counts were adjusted with a haemocytometer. Normal agronomic practices were followed throughout the experiment. Four days after induction of resistance, plants were challenged with spore suspension of A. rabiei $\left(1 \times 10^{5}\right.$ spores $\left.\mathrm{L}^{-1}\right)$ after adding three drops Tween 80 per liter as a wetting agent with a lady hand sprayer until runoff in the evening since temperatures are lower at night helping better conidia germination; this was continued for $3 \mathrm{~d}$ to ensure maximum plant infection. Plants were sprinkled with water to maintain the humidity level for the conidial germination of the fungus. Data on disease reduction percentage was calculated at a 4, 6, 7, 11, and $14 \mathrm{~d}$ interval by a mixed quantitative and qualitative $0-9$ rating scale and converted to disease percentage reduction by the slightly modified formula from Tivoli et al. (2006):

$\Sigma\left(\mathrm{N}^{\circ}\right.$ of plants in a

$\begin{gathered}\text { Disease } \\ \text { reduction }\end{gathered}=\frac{\text { category value } \times \text { category value }) \times 100}{\text { Total } \mathrm{N}^{\circ} \text { of plants } \times \text { maximum category value }}$

Data were subjected to ANOVA and the significance of treatments was determined by Duncan's multiple range test $(\mathrm{P} \leq 0.05)$ (Gomez and Gomez, 1984; Steel et al., 1997).

\section{RESULTS}

Percentage disease reduction by applying chemicals and plant extracts to ' $\mathrm{C}-44$ '

Disease reduction was highly significant in Ascochyta rabiei $(\mathrm{P} \leq 0.05)$ and observed through pretreatment with different chemical and plant extract doses in cv. C-44 (Figure 1). Maximum efficacy after inoculation with the pathogen was in the aqueous solution of ASM $(79.3 \%)$ while the lowest reduction was exhibited by $\mathrm{KOH}(22.8 \%)$. Applying the aqueous solution of SA revealed a $56.8 \%$ disease reduction. Among the various tested concentrations of SA, ASM, and $\mathrm{KOH}$, the highest dose rates, $(1.5,1.2$, and $75 \mathrm{mM}$ respectively) of these resistance inducing substances were found to be effective against pathogen development, and effectiveness persisted for $14 \mathrm{~d}$ after the induction and inoculation with the pathogen although at all the applied chemical dose rates, significant protection started after day 11 and reached the maximum after $2 \mathrm{wk}$. The three plant extracts were evaluated at 5, 10, and $15 \%$ dose rates and neem leaf extract efficiently suppressed the disease $(43.5 \%$ reduction) while the datura (31.4\%) and garlic (26.7\%) extracts also demonstrated protection, although lower than neem (Figure 1). Furthermore, this protection persisted for $2 \mathrm{wk}$ and the highest concentration was efficient in reducing the disease.

\section{Percentage disease reduction by applying chemicals and plant extracts to ' $\mathbf{P b}-91$ '}

Applied plant extracts $(5,10$, and 15\%) in cv. $\mathrm{Pb}-91$ significantly reduced disease development $(\mathrm{P} \leq 0.05)$. All extracts equally provided reduction $14 \mathrm{~d}$ after inoculation against Ascochyta rabiei under field conditions with neem $(20.0 \%)$, datura (19.5\%), and garlic (13.8\%) (Figure 2). Results for chemicals were significantly different from plant extracts although low disease reduction occurred with SA and ASM (37.2\% and 51.2\%) compared with cv. C-44, which was quite promising for controlling chickpea blight. The lowest disease reduction in $\mathrm{KOH}(17.9 \%)$ was similar to plant extracts.

\section{Percentage disease reduction by applying chemicals and plant extracts to 'Bittle-98'}

The percentage of disease reduction in cv. Bittle- 98 by applying chemical and plant extracts was significant $(\mathrm{P} \leq$ 0.05). Applying chemicals to induce resistance was more efficient than with plant extracts. The highest level of disease reduction was ASM (44.1\%) after $14 \mathrm{~d}$ with a 1.2 $\mathrm{mM}$ concentration (Figure 3 ). $\mathrm{KOH}(16.6 \%)$ had the lowest disease reduction while SA effectively reduced ascochyta blight $(29.1 \%)$. Neem (17.7\%), datura (16.6\%), and garlic (13.1\%) exhibited disease reduction. The effect of all these plant extracts and $\mathrm{KOH}$ is similar, but ASM and SA were superior in protecting chickpea against $A$. rabiei.

\section{DISCUSSION}

Induced resistance has attracted the attention of researchers worldwide as a possible strategy for integrated plant disease management (Sundar et al., 2001). The curative property of SA and its derivatives has been known since Hippocrates described the presence of salicylates to provide relief during childbirth (Weissman, 1991). Significant knowledge advances have been made in the last $20 \mathrm{yr}$ about the metabolism and signaling mechanism in plant defense activation when applying SA (Durner $e t$ al., 1997). The role of SA is well-known at the beginning of defense responses against different abiotic and biotic stress (Catinot et al., 2008). Results have proved that SA can be used to control chickpea blight. Similar reductions (49.5\%) against A. rabiei were achieved (Chaudhry et al., 2001) by applying SA at $1 \mathrm{mM}$ in the susceptible cv. C-727. The effect of SA to induce resistance in groundnut plants against Alternaria alternata was investigated by Chitra et al. (2008). Foliar application of SA at 1 $\mathrm{mM}$ significantly reduced leaf blight disease intensity and increased pod yield under glasshouse conditions. 

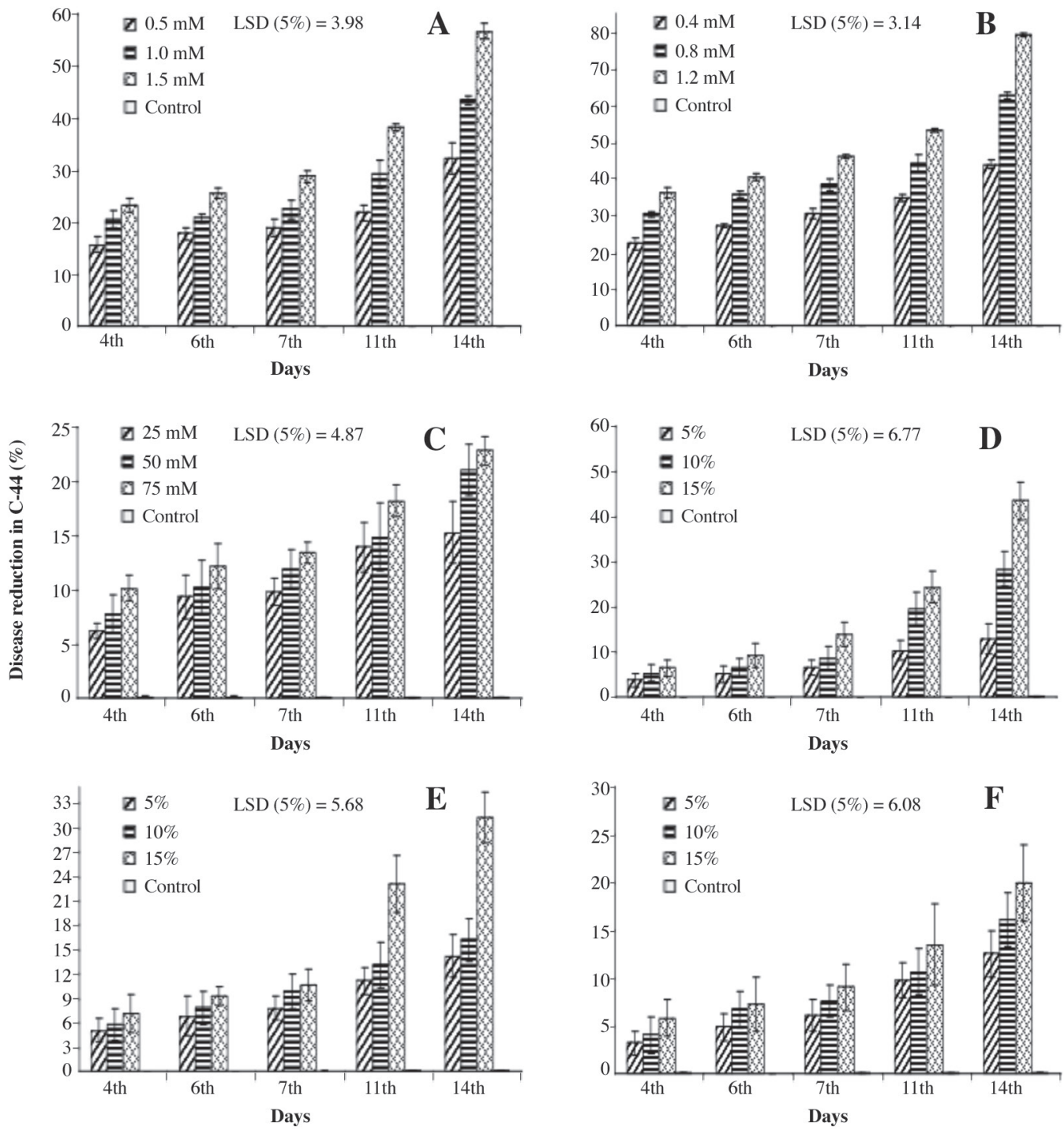

Data are means of three replicates. Error bar represents standard error of the mean according to the least significant difference (LSD) test $(\mathrm{P} \leq 0.05)$.

Figure 1. Mean comparison of percentage reduction in ascochyta blight disease by applying (A) salicylic acid, (B) acibenzolar-S-methyl, (C) KOH, (D) neem, (E) datura, and (F) garlic to cv. C-44.

Foliage spray of $2 \mathrm{mM}$ SA significantly reduced (40.3\%) leaf blight of onion caused by Stemphylium vesicarium under greenhouse conditions $15 \mathrm{~d}$ after inoculation (AboElyousr et al., 2009). The ability of the four chemicals SA, sodium salt of SA, isonicotinic acid, and DL- $\beta$-amino- $n$ butyric acid, as well as the yeast antagonist Cryptococcus flavescens were evaluated against Fusarium head blight (FHB) of wheat under greenhouse conditions showing that NaSA and 2,6-dichloroisonicotinic acid (INA) at 10 $\mathrm{mM}$ significantly reduced FHB severity compared with the non-treated disease control $3 \mathrm{~d}$ prior to challenge with the pathogen (Zhang et al., 2007). The significant trait of the disease resistance inducer is that it persists longer in the host by increasing its biochemical constituents as in this study where SA is still effective against A. rabiei on day 14. Applying a higher concentration of SA at 8 $\mathrm{g} \mathrm{L}^{-1}$ caused more vigorous growth than in the control (Quintanilla and Brishammar, 1998) indicating that increased resistance was obtained in the tuber injected with a higher concentration of SA. After being infected with TMV, a higher accumulation of SA at the infection site was also studied, which may be attributable to transcriptional activation of PR genes in the inoculated and uninoculated leaves (Durner et al., 1997), but this 

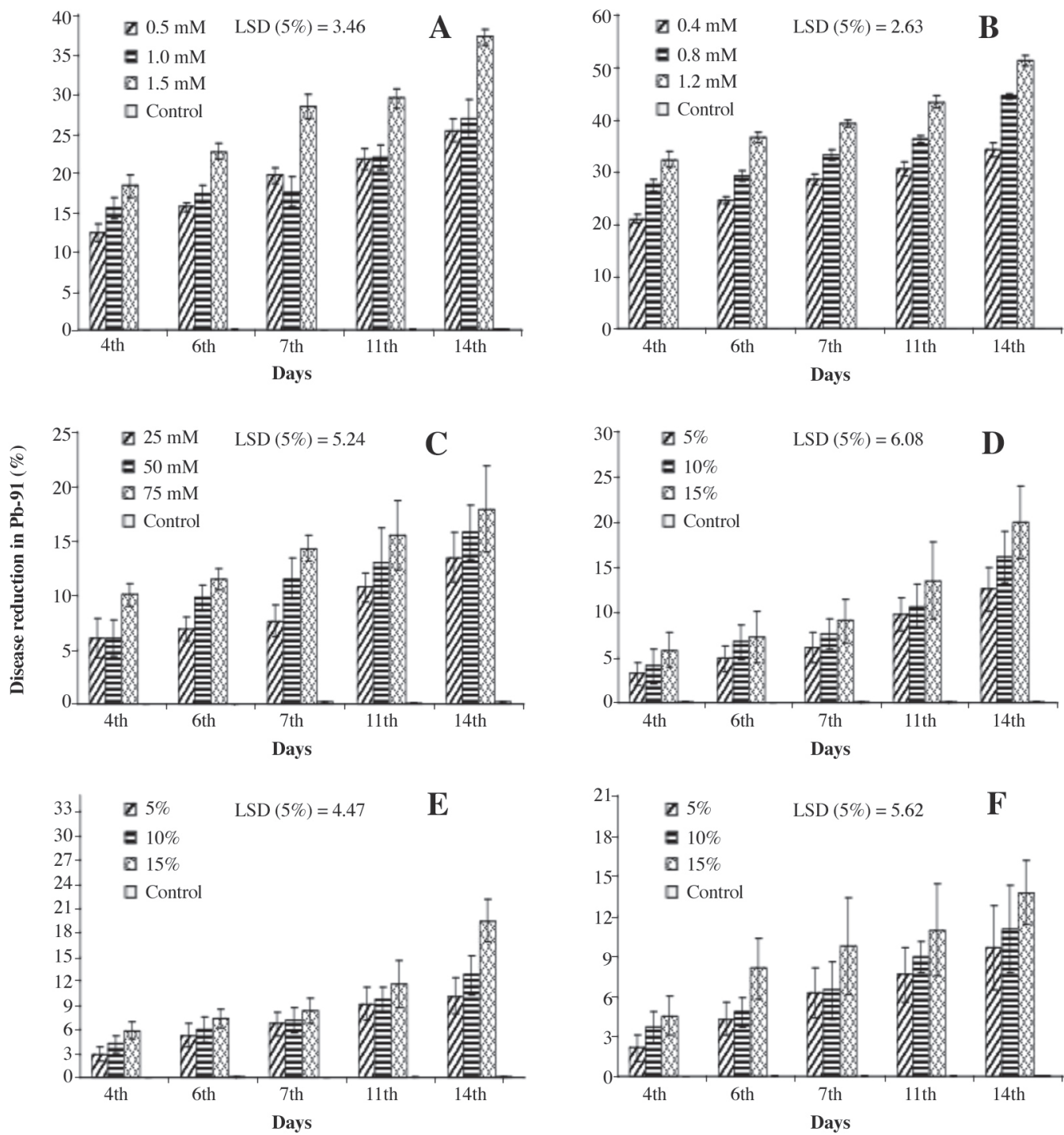

Data are means of three replicates. Error bar represents standard error of the mean according to the least significant difference (LSD) test $(\mathrm{P} \leq 0.05)$.

Figure 2. Mean comparison of percentage reduction in ascochyta blight disease by applying (A) salicylic acid, (B) acibenzolar-S-methyl, (C) KOH, (D) neem, (E) datura, and (F) garlic to cv. Pb-91.

increase was not significant in the uninfected systemic tissue. Kone et al. (2009) studied the induction of disease resistance to Phytophthora capsici on squash by applying DL-3-aminobutyric acid (BABA), 2,6-dichloroisonicotinic acid (INA), Saver (ai: salicylic acid), Syrup (nutrient supplement), and ASM on the mycelial growth in vitro studies and found that only Saver significantly reduced mycelial growth and sporangium production at concentrations of $100 \mathrm{mg} \mathrm{mL}^{-1}$ or higher.

Bion (acibenzolar-S-methyl) was originally marketed to manage powdery mildew of wheat and barley in Europe (Görlach et al., 1996). ASM and INA are considered the best chemical elicitors available to induce resistance. They are considered functional analogs of SA and bring out a systemic form of induced resistance across a broad range of plant pathogens (Friedrich et al., 1996; Maleck et al., 2000). These chemicals did not exhibit any direct antimicrobial activity; however, some instances of antimicrobial activity have been reported in association with high elicitor concentrations (Tosi and Zazzerini, 2000; Rohilla et al., 2002). In our studies, ASM efficiently reduced $A$. rabiei disease and the reduction lasted for 2 wk using the highest concentration. Similar results were obtained by Dann et al. (1998) who studied field and greenhouse experiments from 1993 to 1996 and found that a 20 to $70 \%$ reduction in severity was recorded 

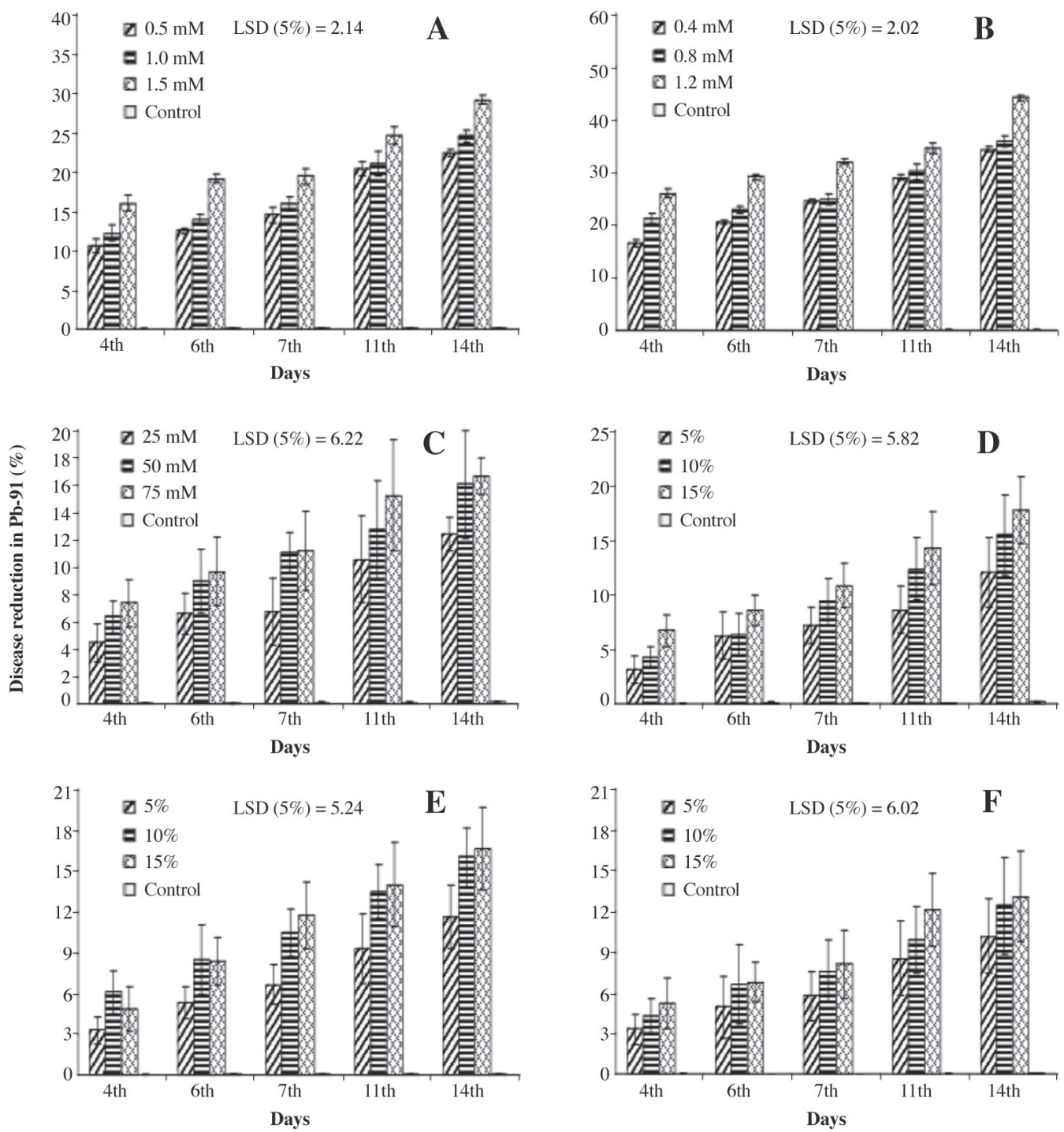

Data are means of three replicates. Error bar represents standard error of the mean according to the least significant difference (LSD) test $(\mathrm{P} \leq 0.05)$.

Figure 3. Mean comparison of percentage reduction in ascochyta blight disease by applying (A) salicylic acid, (B) acibenzolar-S-methyl, (C) KOH, (D) neem, (E) datura, and (F) garlic to cv. Bittle-98.

for three or four applications of 2,6-dichloroisonicotinic acid (DCINA) in soybean cvs. Elgin 87 and Williams 82, which were highly susceptible to Sclerotinia sclerotiorum. This effect was not evident in cvs. Corsoy 79 and NKS1990, which were resistant to white mold disease. Yield also increased, particularly in susceptible cultivars under high disease pressure. Comparable results were also reported by Sundar et al. (2001) as significantly reducing red rot lesion development in sugarcane pretreatment with CGA245704 at $100 \mu \mathrm{g} \mathrm{mL}^{-1}$ applied as soil drench to the potted plants, and effectiveness persisted for up to $30 \mathrm{~d}$ after the treatment. Persistent resistance for longer periods was also reported by Ziadi et al. (2001) against downy mildew of cauliflower.

Dann and Deverall (1996) demonstrated in two consecutive years of field trials that applying 2,6-dichloroisonicotinic acid (INA) to 16- to 20-d-old bean seedlings (cv. Redlands Pioneer) were protected against rust disease caused by inoculation with Uromyces appendiculatus. This protection persisted for $5 \mathrm{wk}$ and the spread of the disease was curtailed to the upper uninoculated leaves so that there was no need to apply further booster doses of INA. Sometimes plants exposed to higher concentrations have also shown phytotoxicity (Louws et al., 2001), but independently of induced resistance. López and Lucas (2002) studied the ability of different resistance inducing 
chemicals to provide protection against anthracnose of cashew caused by Colletotrichum gloeosporioides.

Maximum disease reduction in detached leaves with no phytotoxic effects was obtained with $0.07 \mathrm{mM}$ a.i. ASM and DCINA, $5 \mathrm{mM} \mathrm{SA}$, and $50 \mathrm{mM} \mathrm{K}_{2} \mathrm{HPO}_{4}$ with a time interval of at least $72 \mathrm{~h}$ between activator applications and inoculation with the pathogen. In the case of attached leaves, foliar spray was more efficient than the soil drench treatment. Efficacy of ASM and INA has also been reported in monocots powdery mildew, Septoria leaf spot, and rust of wheat in field trials and solanaceous crops. Effectiveness of BTH applied at 35 g a.i. ha ${ }^{-1}$ at a 7 to $10 \mathrm{~d}$ interval gave promising results to control Xanthomonas axonopodis pv. vesicatoria and Pseudomonas syringae pv. tomato on tomato foliage and fruits, leguminous crops, and white mold of soybean can be controlled by repeated applications of INA, on fruit trees, cotton, and spinach (Vallad and Goodman, 2004). Contrary results of dose-dependent response in ASM were studied by Ajay and Baby (2009) against blister blight disease of tea and showed that applying ASM at a $0.14 \%$ dose rate exhibited $25 \%$ disease protection compared with a $0.18 \%$ (not significant).

Although a substantial number of studies have dealt with phosphate-induced resistance in plants, the primary mode of phosphate action is unknown. It is believed that activation of SAR by locally applying phosphate strongly suggests that it could result either from a translocation of the inducer itself or from signals which initiate an oxidative burst that are generated in phosphate-treated tissues. Applying $\mathrm{KOH}$ in this study was not significant except in cv. C-44 with $23 \%$ disease reduction, which is not considered as satisfactory in any disease control program. Different types of phosphate salt viz dibasic and tribasic sodium or potassium phosphates were highly effective in SAR induction with a $\mathrm{pH}$ value greater than 7 (Gottstein and Kuć, 1989). Foliar application of these phosphate salts induced systemic resistance (ISR) in cucumber (Descalzo et al., 1990), broad bean (Walters and Murray, 1992), grapevine (Reuveni and Reuveni, 1995), maize (Reuveni et al., 1994), pepper (Reuveni and Reuveni, 1995; Reuveni and Reuveni, 1998), and rice (Manandhar et al., 1998) against diversified pathogens belonging to various taxonomic groups. However, all the results are contradictory with our findings and there might be a difference in the selection of $\mathrm{K}$ salts or $\mathrm{pH}$ may be less than 7. On the other hand, applying $50 \mathrm{mM}$ dipotassium hydrogen phosphate provides $51.5 \%$ protection against $A$. rabiei (Chaudhry et al., 2001).

The efficacy of various plant extracts to induce resistance was studied in these experiments; overall results showed that only neem leaf extract at the highest dose rates can provide protection against chickpea blight in cv. C-44 while the effectiveness of datura extracts and garlic is not significant. This lower disease reduction might be due to the lower dose of these plant extracts and perhaps a booster dose was needed but not applied so that these results are from a single application.. The role of plant extracts to induce resistance against plant pathogens has been reported by different researchers. Guleria and Kumar (2006) found that aqueous leaf extract of neem controlled Alternaria leaf spot of sesame. The efficacy of neem leaf extract has also been reported by Paul and Sharma (2002) and it had the same effect as bavistin in managing leaf stripe pathogen of barley.

Antimicrobial activity and induction of systemic resistance by Datura metal leaf extract against Rhizoctonia solani and Xanthomonas oryzae pv. oryzae in rice has been investigated (Kagale et al., 2004) and it was found that foliar application of leaf extract effectively reduced the incidence of sheath blight and bacterial blight of rice. Satya et al. (2007) applied aqueous leaf extract of zimmu (Allium sativum L. x Allium cepa L.) to first and second leaves cotton plants that induced systemic resistance in third and fourth leaves and reduced the number of lesions by up to $73 \%$ after challenged infection with Xanthomonas campestris pv. malvacearum compared with water-treated control plants. This might be due to the fact that active ingredients in these plants can enhance biochemical substances when applied as allicin extract from A. sativum and oxalate as active components of spinach and rhubarb leaves, which can reduce plant diseases by accumulated SA (Doubrava et al., 1988; Slusarenko et al., 2008). It has been effectively used against different plant pathogens, such as Alternaria solani, Pseudomonas syringae pv. tomato (Pst), Xanthomonas vesicatoria (Xv), and Clavibacter michiganensis sub-sp. michiganensis $(\mathrm{Cmm})$ of tomato and induce disease resistance (Balestra et al., 2009; Latha et al., 2009). Roth et al. (2000) studied the effects of an extract of Lychnis viscaria L. seeds that contains brassinosteroids, an aqueous application enhanced by $36 \%$ resistance to tobacco, cucumber, and tomato against viral and fungal pathogens by increasing PRproteins, peroxidase, chitinase, and $\beta$-1,3-glucanase. The disease-controlling ability of Datura metel against plant pathogens and as an inducer of resistance is well documented in the literature as A. rabiei (Shafique and Shafique, 2008), Pennisetum glaucum, and Sclerospora graminicola in pearl Millet (Devaiah et al., 2009).

\section{CONCLUSIONS}

We concluded that resistance inducing chemicals have the potential to control chickpea blight when applied at the proper time and dose rate. These chemicals can 
be integrated with suitable fungicides since they have a synergistic effect with fungicides and persist longer; it would help reduce the number of fungicide applications by enhancing the natural resistance of chickpea cultivars even if they were susceptible to A. rabiei. Plant extracts can be used, but at higher dose rates and combined with resistance inducing chemicals to control chickpea blight.

\section{ACKNOWLEDGEMENTS}

The researcher is highly obliged to Dr. Shakeel Ahmad, Head of Research and Development Syngenta, Pakistan for providing Bion and his assistance to import it from Germany.

\section{RESUMEN}

Inducción de resistencia en garbanzo (Cicer arietinum L.) contra Ascochyta rabiei por la aplicación de productos químicos y extractos vegetales. Debido a la escasez de nuevos fungicidas en el mercado y problemas ambientales, los investigadores están ahora enfatizando otras alternativas, tales como potencial genético de las plantas, resistencia contra patógenos y uso de agentes bióticos y abióticos para el desarrollo de resistencia inducida y adquirida. Investigamos el rol de sustancias inductoras de resistencia (químicos y extractos vegetales) en tres cultivares de garbanzo 'C-44', 'Pb-91', 'Bittle-98', en experimentos de campo contra tizón por Ascochyta. Estos cultivares se seleccionaron basado en el mejor potencial de rendimiento mostrado en experimentos previos. Solución acuosa de ácido salicílico (SA) a 0,5 ;

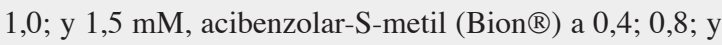
$1,2 \mathrm{mM}$ y $\mathrm{KOH}$ a 25, 50, y $75 \mathrm{mM}$ se aplicaron mientras los extractos vegetales de Azadirachta indica A. Juss., Datura metel L. y Allium sativum L. se aplicaron a 5, 10, y $15 \%$. Datos de reducción en la enfermedad se registraron con diferentes intervalos desde 4 a 14 d después de inducción e inoculación con el patógeno. Los resultados revelaron que ASM 1,2 $\mathrm{mM}$ provocó una reducción significativa de la enfermedad $(79,3 \%)$ en el cv. C-44 comparado con $\mathrm{SA}$; sin embargo, la menor reducción fue observada para $\mathrm{KOH}$. Entre los extractos vegetales, la máxima reducción de la enfermedad $(43,5 \%)$ se observó con la aplicación de extracto foliar de $A$. indica y los extractos de $D$. metel y A. sativum no fueron efectivos para la reducción de la enfermedad. Los presentes hallazgos sugieren que el aumento de la resistencia antes de la infección de plantas de garbanzo pudo ser un método de control innovador para tizón del garbanzo por Ascochyta.

Palabras clave: Resistencia inducida, acibenzolar-Smetil, ácido salicílico, Azadirachta indica, Datura metel.

\section{LITERATURE CITED}

Abo-Elyousr, K.A.M., and H.H. El-Hendawy. 2008. Integration of Pseudomonas fluorescens and acibenzolar-S-methyl to control bacterial spot disease of tomato. Crop Protection 27:1118-1124.

Abo-Elyousr, K.A.M., A.M. Hussein, A.D. Allam, and M.H. Hassan. 2009. Salicylic acid induced systemic resistance on onion plants against Stemphylium vesicarium. Archives of Phytopathology and Plant Protection 42:1042-1050.

Ajay, D., and U.I. Baby. 2009. Induction of systemic resistance to Exobasidium vexans in tea through SAR elicitors. Phytoparasitica. doi:10.1007/s12600-0090068-x.

Ali, S.R., S.M. Iqbal, U. Iqbal, A. Ghafoor, and A. Akram. 2009. Pathogenic diversity in Ascochyta rabiei (Pass.) Lib. of chickpea. Pakistan Journal of Botany 41:413-419.

Aslam, M. 1984. A review of research on chickpea blight fungus in Pakistan. p. 255. In Sexena, M.C., and K.B. Singh (eds.) Chickpea. ICARDA, Aleppo, Syria.

Balestra, G.M., A. Heydari, D. Ceccarelli, E. Ovidi, and A. Quattrucci. 2009. Antibacterial effect of Allium sativum and Ficus carica extracts on tomato bacterial pathogens. Crop Protection 28:807-811.

Baysal, O. 2001. The induced resistance against fire blight by the plant activator $\mathrm{BTH}\left(\mathrm{BION}^{\circledR}\right)$ or extract of Hedera helix leaves and studies on the mode of action. Thesis Ph.D. Georg-August-Universität, Faculty of Agricultural Sciences, Göttingen, Germany.

Catinot, J., A. Buchala, A.E. Mansour, and J.P. Metraux. 2008. Salicylic acid production in response to biotic and abiotic stress depends on isochorismate in Nicotiana benthamiana. FEBS Letters 582:473-478.

Chaudhry, M.H.Z., N. Sarwar, and F.A. Chaughati. 2001. Biochemical changes in chickpea plant after induction treatment with simple chemical for systemic resistance against Ascochyta blight in the field. Journal of the Chemical Society of Pakistan 23(3):182-186.

Chitra, K., N. Ragupathi, K. Dhanalakshmi, P. Mareeshwari, N. Indra, A. Kamalakannan, et al. 2008. Salicylic acid induced systemic resistant on peanut against Alternaria alternate. Archives of Phytopathology and Plant Protection 41:50-56.

Cohen, Y., M. Reuveni, and A. Baider. 1999. Local and systemic activity of BABA (DL-3-aminobutyric acid) against Plasmopara viticola in grapevines. European Journal of Plant Pathology 105:351-361.

Dann, E.K., and B.J. Deverall. 1996. 2,6-Dichloroisonicotinic acid (INA) induces resistance in green beans to the rust pathogen, Uromyces appendiculatus, under field conditions. Australian Journal of Plant Pathology 25(3):199-204. 
Dann,E., B. Diers, J. Byrum, and R. Hammerschmidt. 1998. Effect of treating soybean with 2,6-dichloroisonicotinic acid (INA) and benzothiadiazole (BTH) on seed yields and the level of disease caused by Sclerotinia sclerotiorum in field and greenhouse studies. European Journal of Plant Pathology 104:271-278.

Descalzo, R.C., J.E. Rahe, and B. Mauza. 1990. Comparative efficacy of induced resistance for selected diseases of greenhouse cucumber. Canadian Journal of Plant Pathology 12:16-24.

Devaiah, S.P., G.H. Mahadevappa, and H.S. Shetty. 2009. Induction of systemic resistance in pearl millet (Pennisetum glaucum) against downy mildew (Sclerospora graminicola) by Datura metel extract. Crop Protection 28:783-791.

Doubrava, N., R. Dean, and J. Kuc. 1988. Induction of systemic resistance to anthracnose caused by Colletotrichum lagenarium in cucumber by oxalates and extracts from spinach and rhubarb leaves. Physiological and Molecular Plant Pathology 33:6979.

Durner, J., J. Shah, and D.F. Kessig. 1997. Salicylic acid and disease resistance in plants. Trends in Plant Science 2:7.

Friedrich, L., K. Lawton, W. Ruess, P. Masner, N. Specker, M. Gut Rella, et al. 1996. A benzothiadiazole derivative induces systemic acquired resistance in tobacco. Plant Journal 10:61-70.

Gan, Y.T., K.H.M. Siddique, W.J. MacLeod, and P. Jayakumar. 2006. Management options for minimizing the damage by ascochyta blight (Ascochyta rabiei) in chickpea (Cicer arietinum L.). Field Crops Research 97:121-134.

Gómez, K.A., and A.A. Gómez. 1984. Statistical procedures for agricultural research. 680 p. $2^{\text {nd }}$ ed. John Wiley \& Sons, New York, USA.

Görlach, J., S. Volrath, F. Knauf-Beiter, G. Hengy, U. Beckhove, K.-H. Kogel, et al. 1996. Benzothiadiazole, a novel class of inducers of systemic acquired resistance, activates gene expression and disease resistance in wheat. Plant Cell 8:629-643.

Gottstein, H.D., and J. Kuc. 1989. Induction of systemic resistance to anthracnose in cucumber by phosphates. Phytopathology 79:176-179.

Guleria, S., and A. Kumar. 2006. Azadirachta indica leaf extract induces resistance in sesame against Alternaria leaf spot disease. Journal of Cell Molecular Biology 5:81-86.

Haware, M.P. 1998. Diseases of chickpea. p. 473-516. In Allen, D.J., and J.M. Lenne (eds.) The pathology of food and pasture legumes. CAB International and ICRISAT, Wallingford, UK.
Ilyas, M.B., M.A. Chaudhary, N. Javed, M.U. Ghazanfar, and M.A. Khan. 2007. Source of resistance in chickpea against Ascochyta blight. Pakistan Journal of Botany 39:1843-1847.

Ilyas, M.B., and I.U. Khan. 1986. A low cost easy technique for the culturing of Ascochyta rabiei fungus. Pakistan Journal of Agricultural Sciences 23:60.

Iqbal, M.J., K. Iftikhar, and M.B. Ilyas. 1993. Evaluation of chickpea germplasm for resistance against blight disease. Journal of Agricultural Research 31:449-453.

Jaganathan, R., and V. Narasimhan. 1988. Effect of plant extracts/products on two fungal pathogens of finger millet. Indian Journal of Mycology and Plant Pathology 18:250-254.

Jiang, S., P. Park, and H. Ishii. 2008. Ultrastructural study on acibenzolar-S-methyl induced scab resistance in epidermal pectin layers of Japanese pear leaves. Phytopathology 98:585-591.

Kagale, S.T., T. Marimuthu, P. Thaynmanavan, P. Nandakumar, and R. Samiyappan. 2004. Antimicrobial activity and induction of systemic resistance in rice by leaf extract of Dathura metel against Rhizoctonia solani and Xanthomonas oryzae pv oryzae. Physiological and Molecular Plant Pathology 65:91100.

Kessmann, H., T. Staub, C. Hofmann, T. Maetzke, J. Herzog, E. Ward, et al. 1994. Induction of systemic acquired disease resistance in plants by chemicals. Annual Review of Phytopathology 32:439-459.

Kombrink, E., and E. Schmelzer. 2001. The hypersensitive response and its role in local and systemic disease resistance. European Journal of Plant Pathology 107:69-78.

Kone, D., A.S. Csinos, K.L. Jackson, and P. Ji. 2009. Evaluation of systemic acquired resistance inducers for control of Phytophthora capsici on squash. Crop Protection 28:533-538.

Kuć, J. 2001. Concepts and direction in induced systemic resistance in plants and its application. European Journal of Plant Pathology 107:7-12.

Latha, P., T. Anand, N. Ragupathi, V. Prakasam, and R. Samiyappan. 2009. Antimicrobial activity of plant extracts and induction of systemic resistance in tomato plants by mixtures of PGPR strains and Zimmu leaf extract against Alternaria solani. Biological Control 50:85-93.

López, A.M.Q., and J.A. Lucas. 2002. Effects of plant defence activators on anthracnose disease of cashew. European Journal of Plant Pathology 108(5):409-420.

Louws, F.J., M. Wilson, L.H. Campbell, A.D. Cuppeles, B.J. Jones, and B.P. Shoemaker. 2001. Field control of bacterial spot and bacterial speak of tomato using a plant activator. Plant Disease 85:481-488. 
Maleck, K., A. Levine, T. Eulgem, A. Morgan, J. Schmid, K.A. Lawton, et al. 2000. The transcriptome of Arabidopsis thaliana during systemic acquired resistance. Nature Genetics 26:403-410.

Manandhar, H.K., H.J. Lyngs Jorgensen, S.B. Mathur, and V.S. Petersen. 1998. Resistance to rice blast induced by ferric chloride, di-potassium hydrogen phosphate and salicylic acid. Crop Protection 17:323-329.

Mohamed, L.B., M. Cherif, M. Harrabi, R.F. Galbraith, and R.N. Strange. 2009. Effect of sowing date on severity of blight caused by Ascochta rabiei and yield components of five chickpea cultivars grown under two climatic conditions in Tunisia. European Journal of Plant Pathology. doi:10.1007/s10658009-9546-8.

Neuhaus, J.M. 1999. Plant chitinases (PR-3, PR4, PR-8, PR-11). p. 77-105. In Datta, S.K., and S. Muthukrishnan (eds.) Pathogenesis-related proteins in plants. CRC Press, Boca Raton, Florida, USA.

Pande, S., K.H.M. Siddique, G.K. Kishore, B. Bayaa, P.M. Gaur, C.L.L. Gowda, et al. 2005. Ascochyta blight of chickpea (Cicer arietinum L.): A review of biology, pathogenicity and disease management. Australian Journal of Agricultural Research 56:317-332.

Paul, K.P., and P.D. Sharma. 2002. Azadirachta indica leaf extract induce resistance in barley against leaf stripe disease. Physiological and Molecular Plant Pathology 61:3-13.

Percival, G.C., K. Noviss, and I. Haynes. 2009. Field evaluation of systemic inducing resistance chemicals at different growth stages for the control of apple (Venturia inaequalis) and pear (Venturia pirina) scab. Crop Protection 28:629-633.

Quintanilla, P., and S. Brishammar. 1998. Systemic induced resistance to late blight in potato by treatment with salicylic acid and Phytophthora cryptogea. Potato Research 41:135-142.

Ray, J. 1901. Les maladies cryptogamiques des végétaux. Revue Generale de Botanique 13:145-151.

Reuveni, R., V. Agapov, and M. Reuveni. 1994. Foliar spray of phosphates induces growth increase and systemic resistance to Puccinia sorghi in maize. Plant Pathology 43:245-250.

Reuveni, R., and M. Reuveni. 1995. Efficacy of foliar application of phosphates in controlling powdery mildew on field-grown winegrapes: effects on cluster yield and peroxidase activity in berries. Journal of Phytopathology 143:21-25.

Reuveni, R., and M. Reuveni. 1998. Foliar-fertilizer therapy-a concept in integrated pest management. Crop Protection 17:111-118.
Rohilla, R., U.S. Singh, and R.L. Singh. 2002. Mode of action of acibenzolar-S-methyl against sheath blight of rice, caused by Rhizoctonia solani Kuhn. Pest Management Science 58:63-69.

Roth, U., A. Friebe, and H. Schnabl. 2000. Resistance induction in plants by a brassinosteroid-containing extract of Lychnis viscaria L. Zeitschrift fur Naturforschung Section C-A Journal of Biosciences 55:552-559.

Satya, V.K., S. Gayathiri, R. Bhaskaran, V. Paranidharan, and R. Velazhahan. 2007. Induction of systemic resistance to bacterial blight caused by Xanthomonas campestris pv. malvacearum in cotton by leaf extract from a medicinal plant zimmu (Allium sativum L. $\mathrm{x}$ Allium cepa L.) Archives of Phytopathology and Plant Protection 40(5):309-322.

Schneider, M., P. Schweizer, P. Meuwly, and J.P. Métraux. 1996. Systemic acquired resistance in plants. International Review of Cytology 168:303-340.

Shafique, S., and S. Shafique. 2008. Antifungal activity of n-hexane extracts of Datura metel against Ascochyta rabiei. Mycopath 6(1\&2):31-35.

Slusarenko, J.A., A. Patel, and D. Portz. 2008. Control of plant diseases by natural products: Allicin from garlic as a case study. European Journal of Plant Pathology 121:313-322.

Steel, R.G.O., J.H. Torrie, and D. Dickey. 1997. Principles and procedures of statistics. A biometrical approach. $3^{\text {rd }}$ ed. McGraw-Hill, New York, USA.

Sticher, L., B. Mauch-Mani, and P.J. Metraux. 1997. Systemic acquired resistance. Annual Review of Phytopathology 35:235-270.

Sundar, A.R., R. Velazhahan, R. Viswanathan, P. Padmanaban, and P. Vidhyasekaran. 2001. Induction of systemic resistance to Colletotrichum falcatum in sugarcane by a synthetic signal molecule, acibenzolarS-Methyl (CGA-245704). Phytoparasitica 29:231242.

Tivoli, B., A. Baranger, C.M. Avila, S. Banniza, M. Barbetti, W. Chen, et al. 2006. Screening techniques and sources of resistance to foliar diseases by major necrotrophic fungi in grain legumes. Euphytica 147:223-253.

Tosi, L., and A. Zazzerini. 2000. Interactions between Plasmopara helianthi, Glomus mosseae and two plant activators in sunflower plants. European Journal of Plant Pathology 106:735-744.

Trapero-Casas, A., and W.J. Kaiser. 2009. Alternative host and plant tissue for the survival, sporulation and spread of the Ascochyta blight pathogen in chickpea. European Journal of Plant Pathology 125:573-587. 
Türkkan, M., and F.S. Dolar. 2009. Determination of pathogenic variability of Didymella rabiei, the agent of ascochyta blight of chickpea in Turkey. Turkish Journal of Agriculture and Forestry 33 doi:10.3906/ tar-0901-34.

Vallad, G.E., and R.M. Goodman. 2004. Systemic acquired resistance and induced systemic resistance in conventional agriculture. Crop Science 44:19201934.

Van Loon, L.C. 1997. Induced resistance in plants and the role of pathogenesis-related proteins. European Journal of Plant Pathology 103:753-765.

Walter, D.R. 2009. Plant in the field already induced? Implications for practical disease control. Crop Protection 28:459-465.

Vimala, R., and M. Suriachandraselvan. 2009. Induced resistance in bhendi against powdery mildew by foliar application of salicylic acid. Journal of Biopesticides 2:111-114.
Walters, D.R., and D.C. Murray. 1992. Induction of systemic resistance to rust in Vicia faba by phosphate and EDTA: Effects of calcium. Plant Pathology 41:444-448.

Weissman, G. 1991. Aspirin. Scientific American 264:8490.

Zhang, S., D.A. Schisler, M.J. Boehm, and P.J. Slininger. 2007. Utilization of chemical inducers of resistance and Cryptococcus flavescens $\mathrm{OH} 182.9$ to reduce Fusarium head blight under greenhouse conditions. Biological Control 42:308-315.

Ziadi, S., S. Barbedette, F.J. Godard, C. Monot, D. Le Corre, and D. Silue. 2001. Production of pathogenesisrelated proteins in the cauliflower (Brassica oleracea var. botrytis)-downy mildew (Peronospora parasitica) pathosystem treated with acibenzolar-S-methyl. Plant Pathology 50:579-586. 